Arab Univ. J. Agric. Sci., Ain Shams Univ., Cairo, 14(1), 321-335, 2006

\title{
EFFECT OF SOME SLOW RELEASE N FERTILIZERS ON GROWTH AND FRUITING OF TWO MANGO CVS; FIGRI KELAN AND KEITT
}

[21]

\begin{abstract}
This study was conducted for comparing three slow release $\mathrm{N}$ fertilizers namely, sulphur-coated urea (SCU), phosphorus - coated urea (PCU) and Enciabene with the conventional fast release $\mathrm{N}$ fertilizer namely ammonium nitrate each at the recommended rate of $\mathrm{N}$ i.e., $1000 \mathrm{~g} \mathrm{~N} /$ tree/year for growth characters on the three growth flushes, percentages of leaf N, P and K in the Spring growth cycle, date of first bloom, number of panicles/tree, fruit retention \%, yield as well as physical and chemical characters of fruits in two mango cvs Figri Kelan and Keitt during 2004 and 2005 seasons. Results showed that suppling the trees of both mango cvs with the three slow release $\mathrm{N}$ fertilizers were superior to the application of the fast one in improving shoot length, number of leaves / shoot and leaf area in the three growth cycles, percentages of leaf $\mathrm{N}$, number of panicles / tree as well as physical and chemical properies of the fruits. The slow release $\mathrm{N}$ fertilizers slightly advanced first bloom date. Application of sulphur-coated urea (SCU), phosphorus-coated urea (PCU) and Enciabene (ENC) in a descending order, was very favorable in this connection. These results were true for both mango cvs. It is suggested to fertilize the trees of both mango cvs Figri Kelan and Keitt with $\mathrm{N}$ at $1000 \mathrm{~g} /$ tree/year as sulphur-coated urea fertilizer $(2.4 \mathrm{Kg} /$ tree/year $)$ for obtaining an economical yield with fairly good fruit quality.
\end{abstract}

Keywords: Mango trees, Fertilization, Slow release, Growth, Friuting

\section{INTRODUCTION}

Mango cvs Firgri Kelan and Keitt as prime mango growth under Upper Egypt conditions still need a lot of studies about the type and exact rate of $\mathrm{N}$ required to produce the maximum yield and to improve fruit quality. Recently, new techniques for fertiliztion of fruit trees grown under sandy soil were arisen. Out of those, the application of controlled release $\mathrm{N}$ fertilizers. They were developed mainly to reduce the number of applications per year, minimize the cost of production, improve the efficeny of $\mathrm{N}$ used by trees, reactions and the rapid

1- Tropical Fruit Dept.; Hort. Res. Instit.; Agric. Res. Center, Giza , Egypt

(Received November 19, 2005)

(Accepted December 19, 2005) 
denitrification (Travis, 1971; Nijjar, 1985; Allen, 1986 and Alva, 1992). The control and continous providing of the trees with their requirements from $\mathrm{N}$ can be achieved by using controlled release $\mathrm{N}$ fertilizers which are responsible for releasing their own $\mathrm{N}$ at a longer peroid and at the critical date of fruit development.

Previous studies showed that using slow release $\mathrm{N}$ fertilizers was preferable than using the fast one in improving growth cirteria (Jackson and Davies, 1984; Marler et al 1987; Yuda et al 1987; Ferguson et al 1988; Zekri and Koo, 1991; Alva et al 1993 and Alva and Tucker, 1996), nutritional status of the trees (Maquireiro et al 1984; Koo 1986; Scuderi et al 1993 and Akl et al 2002) and fruiting (Koo, 1988; Boman, 1993; Ahmed et al 1997 and Akl et al 2002).

This study was conducted to compare three controlled release $\mathrm{N}$ fertilizers with the conventional fertilizer i.e ammonium nitrate on growth and fruiting of Firgri Kelan and Keitt mango trees grown in sandy soil .

\section{MATERIAL AND METHODS}

This investigation was carried out during 2004 and 2005 seasons on 24 trees rearly uniform in vigour of 15 years old Firgri Kelan and Keitt mango trees budded on the same rootstock (Balady mango) transplants in the Tropical fruit department Farm, Horticultural Research Institute at Kom-Ombo district, Aswan Governorate. The trees of each mango cv were planted in sandy loam soil at $7.0 \mathrm{x}$ 7.0 meters apart.. Analysis of the tested soil according to (Wilde et al 1985) is shown in Table (1).
Table 1. Mechanical physical and chemical analysis of the tested orchard soil

\begin{tabular}{|cc|}
\hline Sand \% & 56.30 \\
\hline Silt $\%$ & 29.20 \\
\hline Clay $\%$ & 14.50 \\
\hline Texture & Sandy loam \\
\hline $\mathrm{pH}$ & 7.92 \\
\hline E.C. $(\mathrm{dsm})^{-1}$ & 0.95 \\
\hline O . M . \% & 1.80 \\
\hline Total Ca Co $\%$ & 2.33 \\
\hline Total N \% & 0.09 \\
\hline Avialable P $(\mathrm{ppm})$ & 11.0 \\
\hline Avialable K $(\mathrm{ppm})$ & 300.00 \\
\hline
\end{tabular}

This experiment included the following four treatments for each mango cv.

1- Application of sulphur-coated urea (SCU, $41 \% \mathrm{~N}$ ) at the recommended rate of $\mathrm{N}$ namely, $1000 \mathrm{~g} /$ tree $(2.4 \mathrm{~kg} /$ tree).

2- Application of phosphorus-coated urea (PCU, 37.11\% N) at the recommended rate of $\mathrm{N}(2.50 \mathrm{Kg} /$ tree $)$.

3- Appication of Eciabene (ENC, $40 \% \mathrm{~N}$ ) at the recommeneded rate of $\mathrm{N}(2.50$ $\mathrm{Kg} /$ tree).

4- Application of ammonium nitrate (AN $33.33 \% \mathrm{~N}$ ) at the recommended rate of $\mathrm{N}(3.0 \mathrm{Kg} /$ tree $)$.

Each treatment was replicated three times, one tree per each for both mango cvs.. The design of experiment was completely randomized blocks. The three slow release $\mathrm{N}$ fertilizers at the prementioned amounts were applied once in circular digs around each tree $50 \mathrm{~cm}$ apart from trunk and covered with soil. 
The soluble $\mathrm{N}$ fertilizer; ammonium nitrate was added twice at Spring growth cycle start $\left(1^{\text {st }}\right.$ week of March) and just after fruit setting (last week of April). The treated trees received the basal $\mathrm{P}$ and $\mathrm{K}$ fertilizers. Other hortiucultural practices were carried out as usual.

Shoot length $(\mathrm{cm})$ number of leaves and leaf area $(\mathrm{cm})^{-2}$ according to (Ahmed and Morsy, 1999) were mearsued in the Spring, Summer and Autumn flushes in the two mango cvs.

Samples of twenty leaves from the 6 month old shoots from the Spring growth cycle $\left(1^{\text {st }}\right.$ week of September) were selected to determine percentages of $\mathrm{N}, \mathrm{P}$ and $\mathrm{K}$ (on dry weight basis) according to the methods outlined by (Wilde et al 1985) .

First bloom date was recorded. Number of panicles/tree was also counted. Percentage of fruit retention was calculated by dividing the number of retained fruits up to the date of harvest by the total number of fruit set at pea stage and multiplying the product by 100 .

The yield of each tree was recorded (in $\mathrm{Kg}$ ) at harvesting time in both mango cvs.. Samples of twenty fruits were taken from each replicate for measuring the following physical and chemical properties :

1. Average fruit weight (g) and dimensions $(\mathrm{cm})$.

2. Total soluble solids $\%$ by handy refractometer.

3. Total and reducing sugars percentages using Lane and Eynon procedure (A.O. A.C., 1985 ).

4. Non-reducing sugars percentage.

5- Total acidity percentage (expressed as $\mathrm{g}$ tartaric acid/ $100 \mathrm{~g}$ pulp) by titration with $0.1 \mathrm{~N} \mathrm{Na} \mathrm{OH}$ using phenolphthalein as an indicator (A.O. A.C., 1985).

6. Ascorbic acid content (expressed as $\mathrm{mg}$ per $100 \mathrm{~g}$ pulp) by the use of 2.6- dichlorphenolendophenol method (A.O.A.C., 1985).

All the obtained data were tabulated and statistically analyzed according to Mead et al (1993) using New L.S.D test at $5 \%$ level for differentiating between various treatment means.

\section{RESULTS AND DISCUSSION}

\section{1- Growth characters in the three growth flushes}

It is clear from the data in Table (2) that varing the source of slow and fast release $\mathrm{N}$ fertilizers significantly affected the three growth parametrs namely shootlength, number of leaves/shoot and leaf area in both mango cvs.. Fertilizing the three slow release $\mathrm{N}$ fertilizers surpassed the application of the fast one in stimulating each growth character was attributed to using SCU, PCU and ENC, in a descending order. Supplying the trees with SCU and ammonium nitrate gave the maximum and minimum values, respectively. These findings were true in both seasons and in both mango cvs.

The effect of the slow release $\mathrm{N}$ fertilizers in improving the growth of the trees could be attributed to their effect on regulating the release of its own $\mathrm{N}$ as the plants needed. Also they gave the highest values of residual $\mathrm{N}$ due to their low activity index, while those soluble one gave the lowest values of available $\mathrm{N}$ left in the soil. In addition, the role of $\mathrm{N}$ as a constituent of amino acids and proteins as well as its important effect in encouraging cell division and the 
Mohamed and Sanaa Ebeed

Arab Univ. J. Agric. Sci., 14(1), 2006 
Arab Univ. J. Agric. Sci., 14(1), 2006 
development of meristemtic tissues (Nijjar, 1985) can give an explanation for the present effect of such slow release $\mathrm{N}$ fertilizers in activating the growth.

These results are in agreement with those obtained by Jackson and Davies (1984); Marler et al (1987); Yuda et al (1987); Ferguson et al (1988); Zekri and Koo (1991) and Alva and Tucker (1996).

\section{Leaf content of $N P$ and $K$}

Data in Table (3) clearly show that the percantages of $\mathrm{N}, \mathrm{P}$ and $\mathrm{K}$ in the leaves of mango cvs Firgri Kelan and Keitt were significantly varied according to the sources of slow and fast release $\mathrm{N}$ fertilizers. Percentages of $\mathrm{N}$ was maximized in the trees treated with the three slow release $\mathrm{N}$ fertilizers compared to using the fast release $\mathrm{N}$ fertilizer. However, treating the trees with ammonium nitrate was significantly accompanied with maximizing percentages of $P$ and $K$ rather than using the three slow release $\mathrm{N}$ fertilizers. Amending the trees with sulphur-coated urea (SCU), phosphorus-coated urea (PCU) and Ecniabene (ENC) in a descending order was accompanied with maximizing these nutrients.

The minimum values of $\mathrm{N}$ and the maximum values of both $P$ and $K$ were recorded in the trees fertilized with ammonium nitrate . Using sulphur-coated urea had the maximum values of these nutrients compared to the other slow release $\mathrm{N}$ fertilziers. These results were true in 2004 and 2005 seasons in both mango cvs.

The great reduction in $\mathrm{N}$ loss and the increase in plant uptake of $\mathrm{N}$ due to application of the slow release $\mathrm{N}$ fertilizers could expalain the reason of their effect in improving the leaf status of $\mathrm{N}$. However, the observed reduction in the leaf content of both $\mathrm{P}$ and $\mathrm{K}$ due to application of these fertilizers could be attributed to the great consumption of these nutrients to face the increase in vegtative growth (dilution factor). The reduction in $\mathrm{N}$ uptake in response to the application of the fast release $\mathrm{N}$ fertilizer ammonium nitrate was mainly attributed to the great leaching of $\mathrm{N}$ from soil through drainge water, especially in sandy soils.

These finding are in accordance with those obtained by Maquireiro et al (1984); Scuderi et al (1993) and Akl et al (2002).

\section{First bloom date}

As shown in Table (4) using slow release $\mathrm{N}$ fertilizers clearly advanced first bloom date in comparsion with the use of Ammnonium nitrate.

Fertilizing with sulphur-coated urea achieved the earliest date of first bloom. The greatest delay on first bloom was observed on the trees fertilized with ammonium nitrate. These result confirmed the beneficial effect of slow release of $\mathrm{N}$ on advancing blooming stages in both mango cvs Firgri Kelan and Keitt. this is true in both 2004 and 2005 seasons.

\section{No. of panicles/tree, fruit retention $\%$ and yield / tree}

It is obvious from the data in Table (4) that the great and significant differences on number of panicles/tree, fruit retention $\%$ and yield/ tree were observed among the four sources of $\mathrm{N}$. They were 
Arab Univ. J. Agric. Sci., 14(1), 2006 
Arab Univ. J. Agric. Sci., 14(1), 2006 
significantly maximized in response to application of the three slow release $\mathrm{N}$ fertilizers compared to using the fast one. Supplying the trees of mango cvs Firgri Kelan and Keitt with SCU, PCU and ENC, in a descending order, succeeded in obtaining the highest values. The minimum values were detected on the trees fertilized with ammonium nitrate. The mango cv. Firgri Kelan produced 90 and $120 \mathrm{Kg}$ under fertilization with SCU, while those fertilized with ammonium nitrate gave 70 and $89 \mathrm{Kg}$ in both seasons respectively. In the mango cv, Keitt the trees fertilized with SCU produced 55 and $80 \mathrm{Kg}$ in 2004 and 2005 seasons, respectively. Yield in such $\mathrm{cv}$. that received ammonium nitrate reached 35 and $58 \mathrm{Kg}$ in both seasons, respectively. These results were true in 2004 and 2005 seasons in mango cvs Firgri Kelan and Keitt.

The more avialbility of $\mathrm{N}$ for growth and fruiting in the slow release $\mathrm{N}$ fertilizers and the promoption on nutritional status of the trees could explain the improving effect of these slow release $\mathrm{N}$ fertilizers on the yield. Also, the great control of $\mathrm{N}$ uptake by the trees due to the application of slow release $\mathrm{N}$ fertilizers makes the ratio between carbohydrates and total nitrogen in favour of producing more flowers. These merits of the slow release $\mathrm{N}$ fertilizers result in a great promotion on fruit set, and consequently, the yield.

These result are in a ccordance with those obtained by Koo, (1986); Koo, (1988); Boman, (1993); Scuderi et al (1993); Wassel et al (2000) and Akl et al (2002).

\section{Fruit Quality}

Data in Table (5 \& 6) clearly show that physical and chemical characters of mango cvs Firgri Kelan and Keitt were greatly varied according to sources of $\mathrm{N}$. Application of the three slow realease $\mathrm{N}$ fertilizers; SCU, PCU and ENC was favourable in improving fruit quality in terms of increasing fruit weigth and dimension, total soluble solids totals sugars, reducing sugars non-reducing sugars and ascorbic acid and in reducing total acidity \% than using ammonium nitrate. The promotion in quality of the fruit was associated with using SCU, PCU and ENC in a descending, order. Unfavourable effects on fruit quality were detected owing to using ammonium nitrate fertilizers. These results were true in 2004 and 2005 seasons in mango cvs Firgri Kelan and Keitt.

The continous release of $\mathrm{N}$ through all tree growth stages especially at fruit development stage due to the application of slow release $\mathrm{N}$ fertilizers could expalin their action on fruit weight. In addition, the important role of $\mathrm{N}$ in stimulating both cell division and cell elongation and the biosythesis of proteins and carbohydrates must be taken into our consideration. The effect of the slow realease $\mathrm{N}$ fertilizers on achieving a good balance between growth and fruiting through adjusting the release of $\mathrm{N}$ is surely reflected on accumulating total carbohydrates and making them available for enhancing the ripening of fruits.

The promoting effect of the slow release $\mathrm{N}$ fertilizers on fruit quailty was confirmed by the resultsd of Ahmed $\boldsymbol{e t}$ al (1997) and Hegab et al (1999). 
Arab Univ. J. Agric. Sci., 14(1), 2006 
As a conclusion, fertilizing the trees of mango cvs Figri Kelan and Keitt with $\mathrm{N}$ at $1000 \mathrm{~g} /$ tree as sulphur-coated urea was beneficial in obtaining an economical yield and improving fruit quality.

\section{REFERENCES}

Ahmed, F.F. and M.H. Morsy, (1999). A new method for measuring leaf area in different fruit species. Minia J. of Agric. Res. and Develop. 19: 97-105, Egypt Ahmed, F.F.; A.A. Gobara and M.S. Hammam, (1997). Effect of some fast and slow fertilizers on fruiting of Williams bananas. Proc. $1^{\text {st }}$ Sci. Conf. of Agric. Sci., Fac. Agric., Assiut Univ. (13-14 Dec.) 1: 125-134, Egypt

Akl, A.M.; F.F. Ahmed; M.Y. Hegab; E.O. Abo El-Komsan and E. YounessRanda (2002). Effect of different sources, levels and methods of nitrogen applications on growth, leaf mineral content, fruit setting, yield and fruit quality of Valencia orange trees. 1-The effect on growth, leaf mineral content and fruit setting. Minia J. of Agric. Res. and Develop. 22(4): 483-500, Egypt .

Allen, S.E. (1986). Slow release nitrogen fertilizers Nitrogen in crop production, 195 - 206 ASA, CSSA, and ASA, Madison. (Cited from the $2^{\text {nd }}$ Scientific Conference of Agricultural Sciences, Assiut, Oct. 2000 pp. $285-291)$.

Alva, A.K. (1992). Differential leaching of nutrients from soluble and controlledrelease fertilizers. Environ. Manage. 16: 769-776.

Alva, A.K. and D.P.H. Tucker (1996). Evaluation of a resin coated nitrogen fertilizer for young citrus trees on a deep sand. Proc. Florida State Hort. Soc., 108: 4-8.
Alva, A.K.; D.P.H. Tucker and H.J. Barrow (1993). Can polyolefin coated nitrogen reduce nitrate leaching and fertilizer requirements for young citrus trees. Proc. $12^{\text {th }}$ Inter. Plant Nutrition Colloquiun (21-26 Sept.) Perth, Australia pp 599-602.

Association of Official Agriculture Chemists (1985). Official Method of Analysis, pp. 494-500, A.O.A.C, Benjamin Frązklin Station, Washington D.C., U.S.A.

Boman, B.J. (1993). Comparison of controlled release to conventional fertilizer on Marsh grapefruit. Proc. Florida State Hort. Soc., 106: 1-4.

Ferguson, J.J.; F.S. Davies; C.W. Matthews and R. Davis (1988). Controlled release fertilizers and growth of young Hamlin orange trees. Proc. Florida State Hort. Soc., 17-20.

Hegab, M.Y.; A.H. Ali and G.M. ElDawwey (1999). Behaviour of Balady mandarin trees (Citrus reticulate L.) grown in sandy soil to some slow release nitrogen fertilizers. Minia J. of Agric. Res. and Develop. 19: 81-96, Egypt. Jackson, L.K. and F.S. Davies (1984). Mulches and slow release fertilizers in a citrus young tree care program. Proc. Florida State Hort. Soc., 97: 37-39.

Koo, R.C.J. (1986). Use of controlled release nitrogen for citrus in a humid region. Citrus Culture, $6^{\text {th }}$ Inter. Citrus Congress, Tel Aviv, Israel, 6-11 March, 2: 633-641.

Koo, R.C.J. (1988). Controlled release sources or nitrogen for bearing citrus. Proc. Florida State Hort. Soc., 99: 4648.

Maquireiro, A.; M.D. Climent; R. Puchades and E.P. Yufera (1984). Fertilization of orange trees with sulphur- 
coated urea. 1- Nitrogen levels in leaves and fruits. Plant and Soil 80(2): 247-254. Marler, T.E.; J.J. Ferguson and F.S. Davies (1987). Growth of young Hamlin orange trees using standard and controlled release fertilizers. Proc. Florida State Hort. Soc., 100: 61-64. Mead, R.; R.N. Currow and A.M. Harted (1993). Statistical Methods in Agriculture and Experimental Biology, $2^{\text {nd }}$ Ed. Chapman \& Hall, London.

Nijjar, G.S. (1985). Nutrition of Fruit Trees. Mrs Usha. Raj Kumar, Kalyani, New Delhi, pp. 306-308.

Scuderi, A.; G. Raciti and A. Barbagallo (1993). Manuring of citrus; nutritional and yield effects of using slow release nitrogen formulations. Informatore Agric. 39(40): 27731-27735.

Travis, P.H. (1971). Controlled-release fertilizers. News 16: 42-48.
Wassel, A.M.; F.F. Ahmed and T.A. Ebrahiem (2000). Nitrogen better management for high yield and quality of Balady mandarin trees grown in sandy soil. The $2^{\text {nd }}$ Sci. Conf. of Agric. Sci. Assiut, pp. 293-300.

Wilde, S.A.; R.B. Corey; J.G. Lyer and G.K. Voigt (1985). Soils and Plant Analysis for Tree Culture, $3^{\text {rd }}$ Ed. pp. 94-100. Oxford, IBH Publishing Co., New Delhi, India.

Yuda, E.; T. Nakagoma; Y. Moriguchi and S. Nokagawa (1987). Effect of controlled release fertilizer on the growth of young Satsuma mandarin trees. J. Plant Nutrition 10: 1471-1478.

Zekri, M. and R.C.J. Koo (1991). Evaluation of controlled release fertilizers for young citrus trees. J. Amer. Soc. Hort. Sci. 116(6): 987-990. 


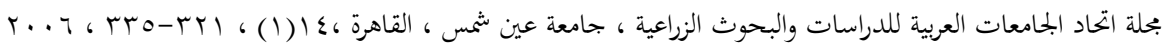
تأثير بعض الأسمدة النيترجينية بطيئة التحلل على النمو و الإثمار في صنفي المانجو الفجري كلان و الكيث

[YI]

\section{'أحمد ياسين محمد' - سناء سامي عيبل'}

- قسم الفاكهة الإستوائية- معهل بحوث البساتين - مركز البحوث الزراعية - الجيزة - مصر

عدد الأوراق على النمو الخضري ومساحة

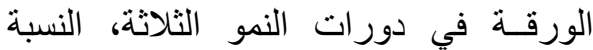

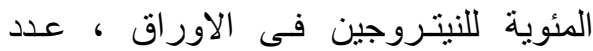
النورات الزهرية على الشجرة ، النسبة النورية المئوية للثمار العاقدة ، كمية المحصول والخصـائص الطبيعيـة و الكيميائية للثمار وكان هناك تبكير طفيف في مو عد الإزهار

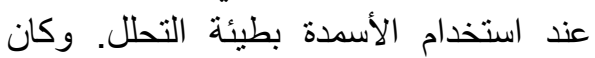
استخدام اليوريا المغطاة بالكبريت ، و اليوريا المغطاة بالفوسفور والإنسيابين مرتبة ترنيباً تنازلياً فعالاً في هذا الصدد وكانت هذه النتائج متماثلة في كلا صنفي المانجو.

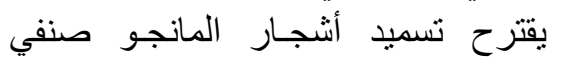
الفجري كلان والكيت بالنيتروجين بمعدل

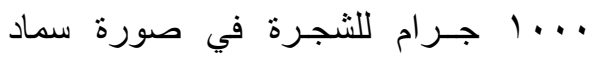

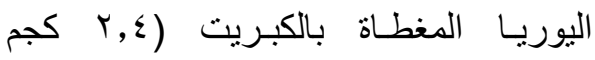
للشجرة) للحصـول على محصول إقتصادي وثمار ذات جودة عالية.
أجريت هذه التجربة لمقارنة تأثيرثلاثنة أسمدة نيتروجينية بطيئة التحلل هي اليوريا

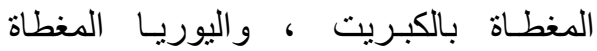
بالفوسفور والإنسيابين ، بالسماد سريع التحلل

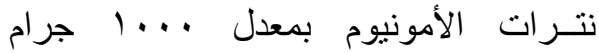

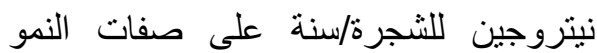
الخضري في دورات النمو الثناثنة، والنسب المئوية للنيتروجين و الفوسفور و البوتاسيوم

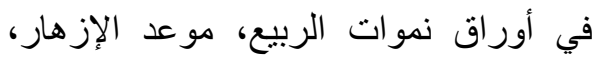

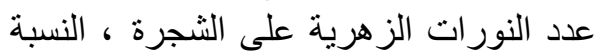

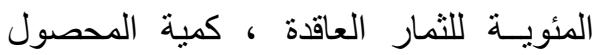
والخصائص الطبيعية والكيميائية للثمار في الفي صنفي المانجو الفجري كلان و الكيت وذللك

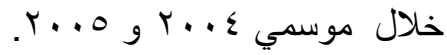

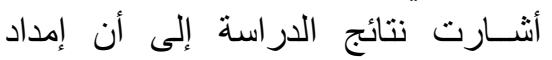
أشجار صنفي المانجو الفجري كلان والكيت بالأسمدة بطيئة التحلل الثلاثة قد تفوق على لى استخدام السماد سريع التحلل وهو نتريه الترات الأمونيوم في تحسين طول النمو الخضري ، هوبر

$$
\text { تحكيم: أ.د محمد أبو رواش على بـدر }
$$

